\title{
STRUCTURAL COST COMPARISON OF LOW RISE BUILDING HAVING MOMENT RESISTING FRAMES AND MOMENT RESISTING FRAMES WITH SHEAR WALL FOR DIFFERENT SCIESMIC ZONES: CASE STUDY
}

\author{
Mukesh Gordhandas Bagani \\ Applied Mechanics Department, R C Technical Institute, \\ Sola, Ahmedabad, India
}

\begin{abstract}
In Bhuj earthquake 2001, there were collapses of many low rise buildings. After a very severe seismic shaking, it may be far cheaper to repair, or even rebuild the damaged structure, than to build a no damaged structure in the first place. With the help of shear walls the structure can be made which will not collapse in earthquake. It is general perception in minds of people that shear walls are economical for high rise buildings. Therefore it is necessary to find out cost efficiency of low rise buildings with shear walls.
\end{abstract}

Keywords: Shear wall, cost effectiveness, low rise building

Cite this Article: Mukesh Gordhandas Bagani, Structural Cost Comparison of Low Rise Building Having Moment Resisting Frames and Moment Resisting Frames with Shear Wall for Different Sciesmic Zones: Case Study, International Journal of Advanced Research in Engineering and Technology, 10 (2), 2019, pp 14-21.

http://iaeme.com/Home/issue/IJARET?Volume=10\&Issue $=2$

\section{INTRODUCTION}

Moment Resisting frames and shear walls frames are two principles structural systems used in reinforced concrete buildings to resist lateral forces generated due to wind and earthquake. Moment resisting frames are considered efficient for buildings having 10 to 15 stories. Tall moment resisting frames are undesirable for resisting lateral forces because if there is an the increase in number of stories, then the size of frame members required to ensure adequate rigidity will lead to corresponding increase in storey height. Large inter storey displacement for such frames can cause severe damage to the moment resisting frames as well as to the nonstructural elements.

Moment resisting frame \& shear wall combined together to form one structural system is called dual system or hybrid system. Dual systems may have combine advantages of their constituent elements. Ductile frames interacting with walls can provide significant amount of 
energy dissipation due to large stiffness of wall, thus in case of multi storey building it is possible to achieve a good storey drift control.

Despite the attractiveness and prevalence of dual systems, this approach is developed since long at world level and recently in India; a research effort has been directed towards the development of relevant seismic design methodologies. The common practise of allocating a portion of the lateral forces to the frames and remainder to the walls, each of which then independently analysed is entirely inappropriate. Compatibility of deformation between two elements must be considered. In this study, with the help of case study, we concentrate on the effect of dual system on overall cost of structure.

\section{DIFFERENT TYPE OF STUCTURAL SYSTEMS}

There are four basic systems for high-rise buildings

1) Moment Resisting Frames

2) Moment Resisting Frames With Shear walls

3) Framed Tube System

4) Tube in Tube System

Table 1 below show the Guide for selection of Structural System

Table 1 Guide for selection of structural System

\begin{tabular}{|c|c|c|c|}
\hline & \multicolumn{2}{|c|}{ Number of storeys } & \multirow[t]{2}{*}{ Seismic behaviour } \\
\hline & $\begin{array}{c}\text { Office } \\
\text { Buildings }\end{array}$ & $\begin{array}{c}\text { Residential Buildings, } \\
\text { Hotels etc }\end{array}$ & \\
\hline Moment Resisting Frames & Up to 15 & Up to 20 & Very good \\
\hline Shear walls & Up to 40 & Up to 150 & Good \\
\hline $\begin{array}{l}\text { Shear wall in conjunction with } \\
\text { frame }\end{array}$ & Up to 40 & Up to 70 & Very Good \\
\hline Single framed Tube & Up to 40 & Up to 60 & Very Good \\
\hline Tube in Tube & Up to 80 & Up to 100 & Good \\
\hline
\end{tabular}

\subsection{Moment resisting frames}

Moment Resisting Frame is space frame designed to carry all vertical and horizontal loads by developing bending moments in the members and at joints. Lateral load resisting capacity of reinforced concrete framed structures depend mainly on rigidity of member connections.

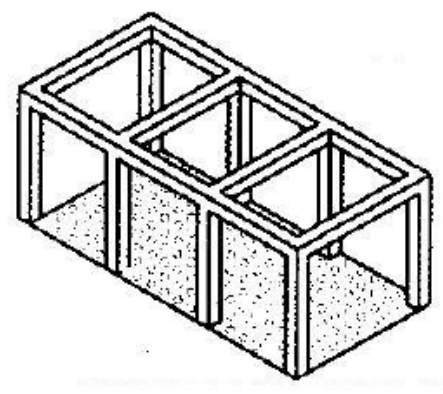

Figure 1 Moment Resisting frames

\subsection{Shear wall}

Shear walls are essentially columns with a large depth and a small width. The walls are quite stiff in their own plane and flexible in the perpendicular plane. Thus a shear wall transfers the 
lateral force in its own plane by developing moment and shear resistance. Large amount of lateral force will be transferred to walls because of moment of inertia and large stiffness of wall.

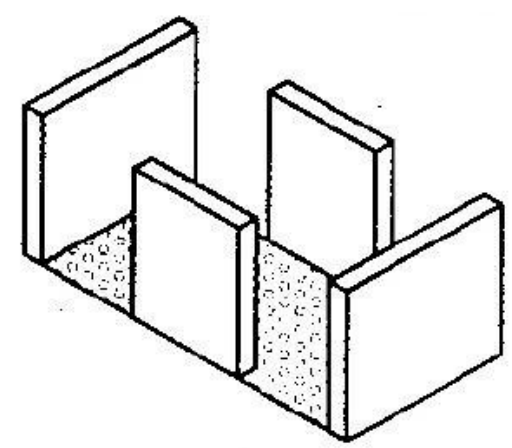

Figure 2 shear wall

\subsection{Moment resisting frames with shear walls (dual system)}

Moment resistant frame with shear walls also termed, as dual system is a space frame with moment resistant joints, strengthened by shear walls to assist in carrying out horizontal loads. This shear wall - frame interactive system, is considered as the best structural system for reinforced concrete multi-storey structures in region of high seismcity. This system combines the gravity load carrying qualities of frames with the lateral load resisting quality of the shear walls. Fig 3 shows reinforced concrete shear walls in buildings.

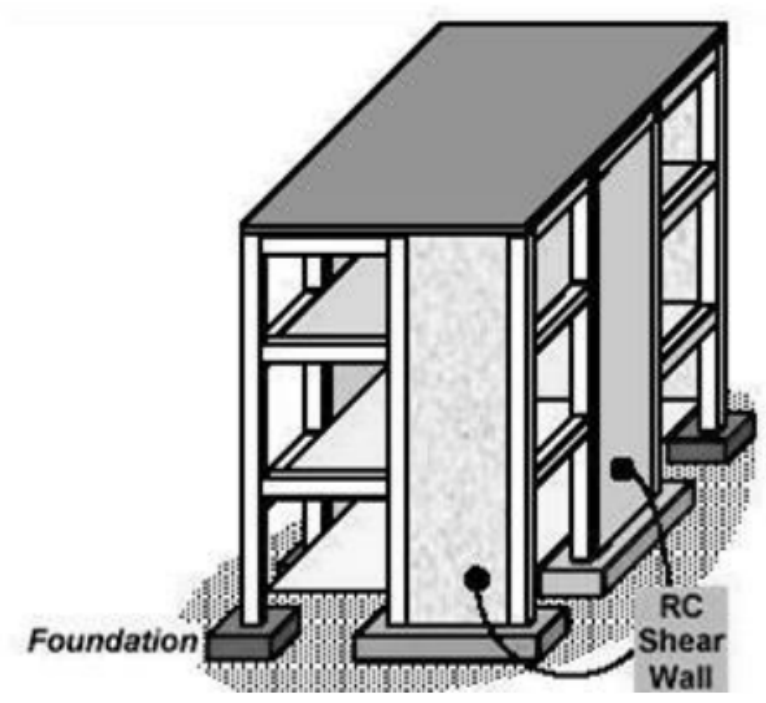

Figure 3 Moment resisting frames with shear walls

\subsection{Interaction between shear wall and frame}

The interaction between the frame and the shear wall reduces the lateral deflection of the structural wall at the top, while the wall helps in supporting the frame near the base. In the building, in plane rigidity of the floor slab forces the deflection of the walls and the frames to be identical at each storey level. To force the wall and the frame into the same deflected shape, internal forces are generated that equalizes the deflected shape, of each. Thus the frame in the upper stories pulls back the wall while in lower stories the wall pushes back the frame. These internal forces shown in Fig 4 
Structural Cost Comparison of Low Rise Building Having Moment Resisting Frames and Moment Resisting Frames with Shear Wall for Different Sciesmic Zones: Case Study

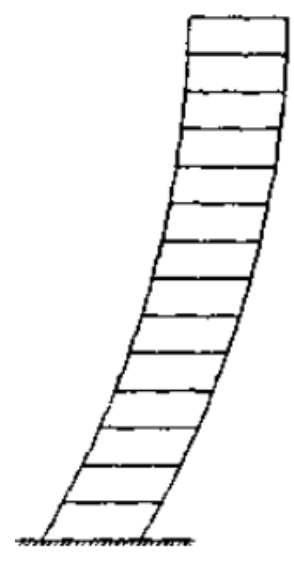

(a) Rigid frame

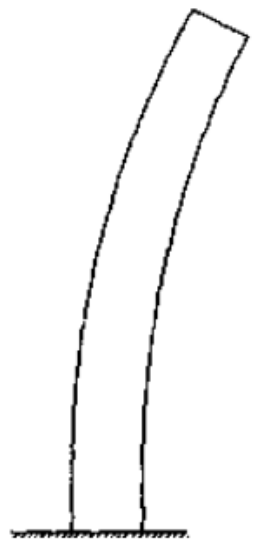

(b) shear wall

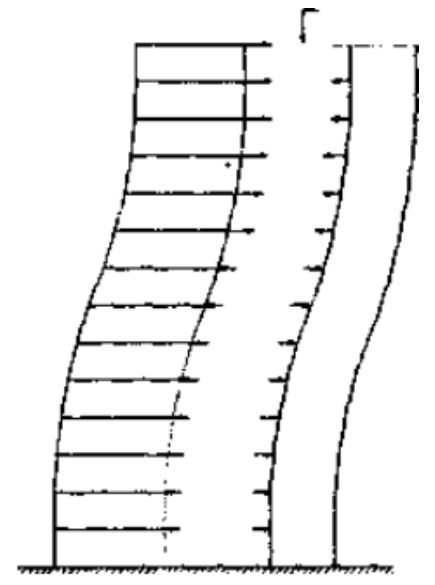

(c) interconnected system

Figure 4 Interaction between shear wall and moment resisting frames

Shear wall greatly reduces the deflection of the overall combine system, creating a considerably overall higher stiffness than the sum of the individual components, each resisting a portion of exterior loads. In this distinctive feature of increasing the stiffness through a set of internal forces lies the great advantage of shear wall frame interactive systems. Like columns shear wall also resist the vertical loads in addition to lateral loads.

The biggest qualification of this system of shear wall frame is in the interaction and due to the lateral rigidity provided by the shear walls the inter storey displacements are reduced and thus, it minimizes the non-structural damages and gives a better performance from the point of view of damage control.

In dual system as explained above the frame and wall combination should be designed to carry the total lateral force due to earthquake acting on the building. The frame acting alone should be designed to resist at least 25 percent of the total lateral force, even if the shear walls share more than $75 \%$ of the total lateral force. This is to take care of the effect of displacement during earthquake.

The shear walls should extend from the foundation either up to top of the building or to a lesser height as required from design consideration. Care should be taken to see that the discontinuity in the shear wall does not produce sudden reduction in stiffness of the structure and can cause soft storey or weak storey.

\section{FORMULATION OF CASE STUDY}

\subsection{General Information of case study building}

For the purpose of case study the apartment building having 4 flats on each story located at Ahmedabad region was taken

\subsection{Methodology of Analysis}

Analysis is done in Staad Pro 2003 and Staad Pro 2005 Software. Building modelled as 3D frame with Shear wall as plate element. Base Shear is applied as per IS 1893-2002. Base shear is distributed as storey shear. Every floor slab is considered as infinitely rigid. For considering rigidity of slab master slave command is used. Support condition is taken as Hinge for column and Shear walls. Study is carried out for Seismic Zones III, IV and V. 


\section{Loadings}

- Slab loading specified in terms of floor load command for two way distribution loading

- Wall load specified in terms of member loading

- Self-weight of columns and beams specified in terms of self-weight command

\section{Earth quake analysis}

- Earth quake loading is specified in terms of code 1893 -2002 parameter related to zone factors.

- Dead load and \% of live loads are used to find out base shear.

- Load combinations are specified for all load specifications

- Location of shear wall is finalized after placing shear wall in different locations. Shear wall having lesser length and attracting more than $75 \%$ of base shear as per code requirement is selected.

In our case study buildings are symmetrical about both axes except mass of stair case is only unsymmetrical which generate eccentricity of $2 \mathrm{Cms}$ only between centre of mass and centre of rigidity. Space frame analysis is performed which takes care of eccentricity

\subsection{Case Study}

For the purpose of case study the apartment building having 4 flats on each story located at Pune region was taken. The case is existing building. Following are silent features of case study.

- This building is $\mathrm{G}+3$ storey residential building. Four flats on each storey.

- Floor area of each floor is $=296.6 \mathrm{~m}^{2}$

- Total built up area of the building $=1186.4 \mathrm{~m}^{2}$

- Total height of building including OHWT is $15.82 \mathrm{~m}$

The structural plan of the selected building has been decided as shown in figure 5
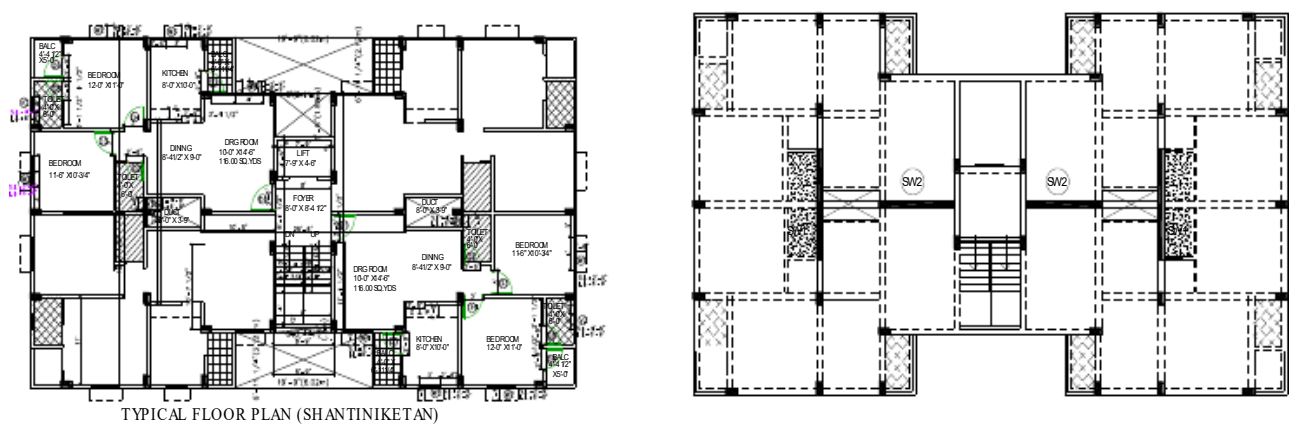

Figure 5 Case study Building Typical floor plan and structural system

The structural plan of the selected building has been decided as shown in figure 5

\subsection{General Analytical approach / assumption used}

Building is considered for same seismic zones as well as having same wind velocity.

3-D analysis is done on computer using software STAAD PRO. 2003 \& STAAD PRO. 2005.Every floor slab is considered as infinitely rigid. For considering rigidity of slab master slave command is used. Support conditions are taken as hinge for columns and shear walls. Shear walls are modelled as plate element. Soil condition is assumed as medium soil having 
Structural Cost Comparison of Low Rise Building Having Moment Resisting Frames and Moment Resisting Frames with Shear Wall for Different Sciesmic Zones: Case Study

soil bearing capacity is assumed is $180 \mathrm{kN} / \mathrm{m}^{2}$. Centre line dimensions / diagrams is considered for columns, beams and walls in computer analysis. In EQ load combinations, the allowable bearing pressure in the soil increased $25 \%$ in case of combined RCC footing with slab beam.In case shear wall with frame analysis case dual system is used so two systems are designed resist the total design force in proportion to their stiffness considering the interaction of the dual at all floor levels. Response reduction factor is taken 5 for all cases as ductility criteria are to be satisfied.

\subsection{Methodology of Design}

Shear wall is provided with initial size in two directions and location in plan such that large eccentricity 'e' from C.G. and C.R. does not generated. Design of shear wall, shear wall footing and column footing is done with Excel spreadsheet, Beam and column design is done with Staad Pro and same also checked with Excel spread sheets. Design and detail of various elements is done. Quantities of materials is found out from drawings. Cost analysis for different cases with and without shear wall is prepared and compared with basic rates in Ahmedabad. Conclusion is worked out from Cost analysis.

\section{RESULTS}

Charts showing below results obtained from analysis and design of building for seismic zone III, IV and V

STRUCTURAL COST FOR CASE STUDY

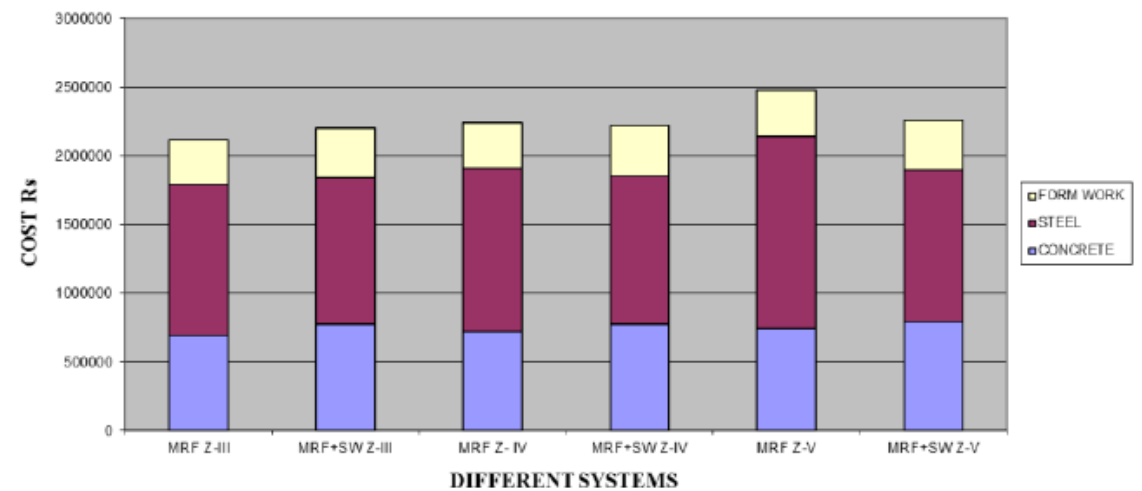

COST COPMPARISON OF DIFF STRUCTURALSYSTEMS \& MATERIALS

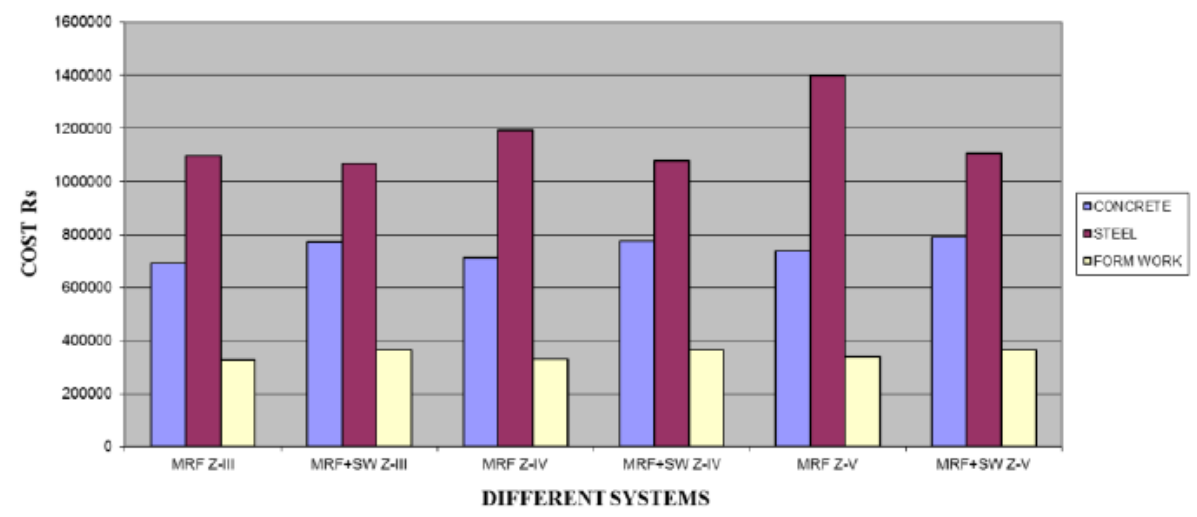


Mukesh Gordhandas Bagani

STR.COST COMPARISON OF MRF WITH MRF+SW IN\%

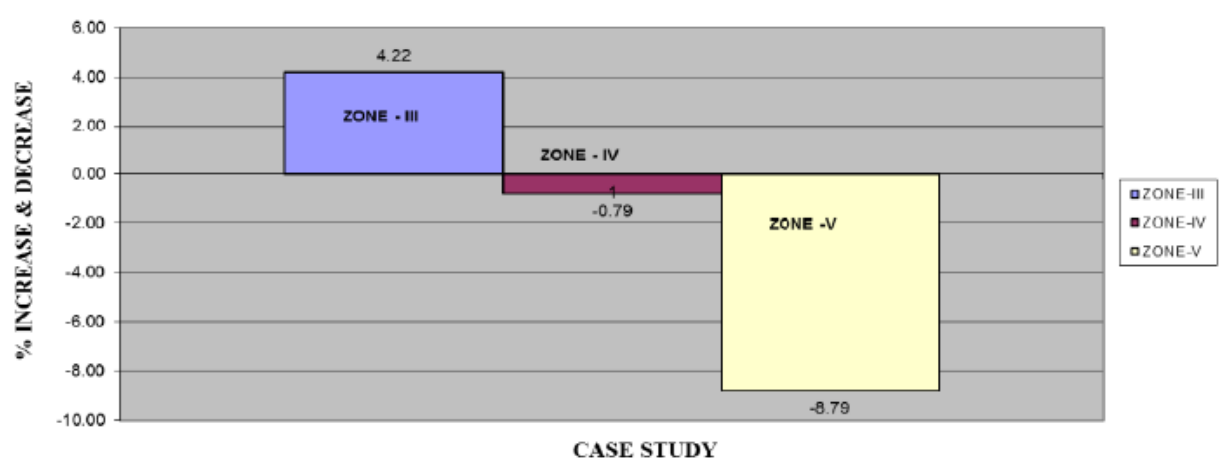

VARIATION OF CONCRETE QUANTITY IN $\mathrm{m}^{3} / \mathrm{m}^{2}$

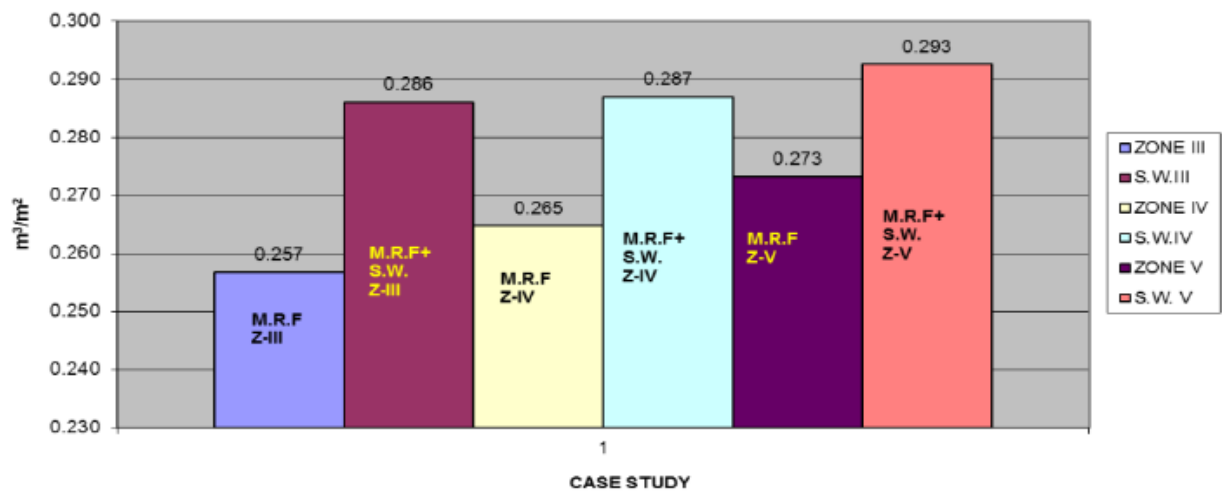

VARIATION OF STEEL QUANTITY IN $\mathrm{Kg} / \mathrm{m}^{3}$

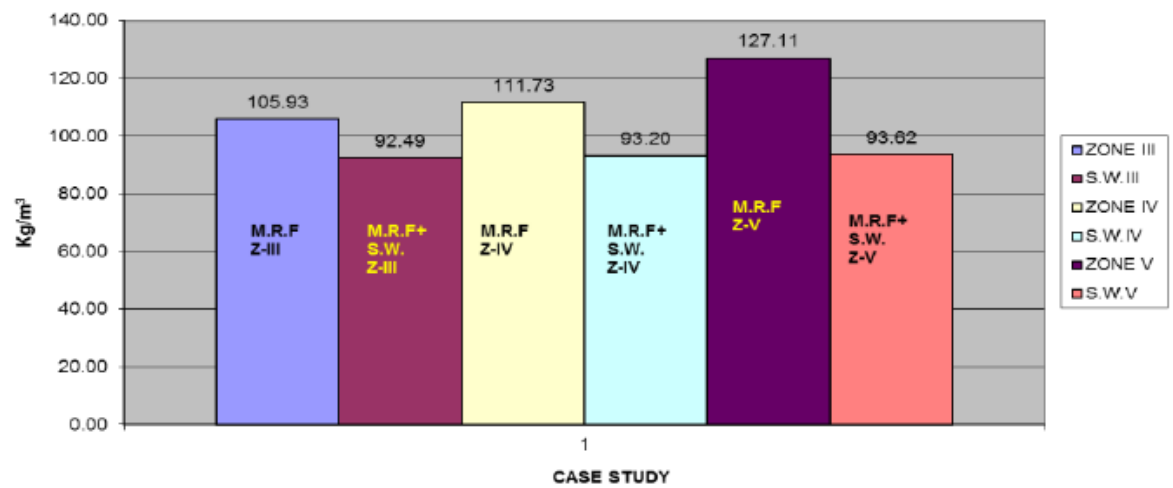

VARIATION OF FORMWORK QUANTITY IN $\left(\mathrm{m}^{2 /} \mathrm{m}^{3}\right)$

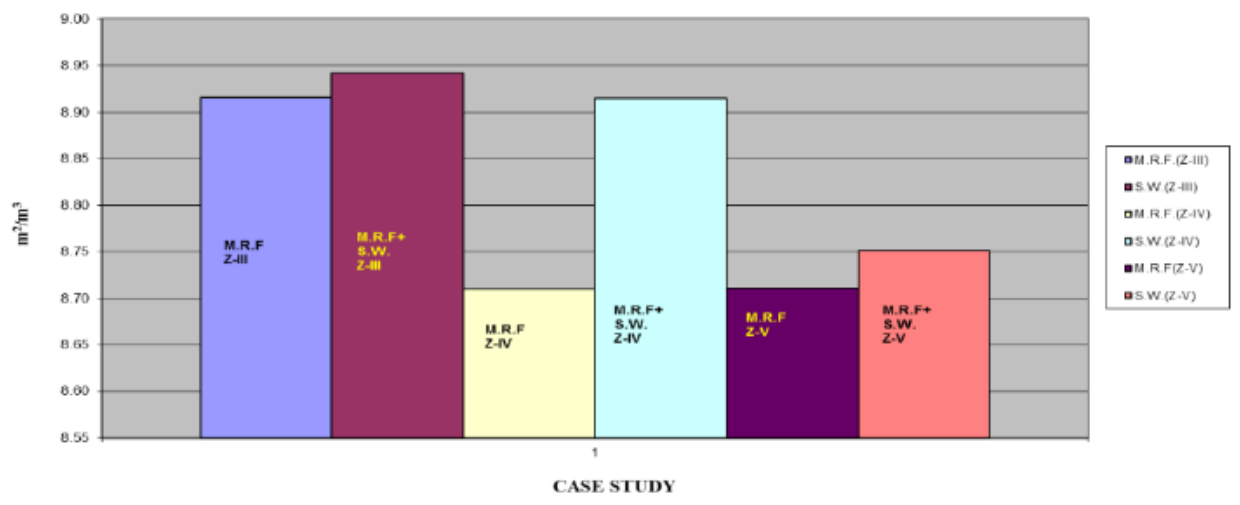


Structural Cost Comparison of Low Rise Building Having Moment Resisting Frames and Moment Resisting Frames with Shear Wall for Different Sciesmic Zones: Case Study

\section{CONCLUSIONS}

(1) From above case study we can conclude that the shear wall is costly in zone III but total structural cost of building is not exceeding $10 \%$

(2) In case 1 Building with shear wall for Zone IV is costly up to $0.79 \%$

(3) In case study shear wall is Economical for zone $\mathrm{V}$

(4) Ratio of Concrete / Area $\left(\mathrm{M}^{3} / \mathrm{M}^{2}\right)$ is increase in Building designed with shear wall than Buildings Designed with only Moment Resisting Frames for all cases

(4) Ratio of Steel/Concrete $\left(\mathrm{Kg} / \mathrm{M}^{3}\right)$ is decreasing in Buildings designed with shear wall than Buildings Designed with only Moment Resisting Frames for all cases

(5) Ratio of Formwork / Concrete $\left(\mathrm{M}^{2} / \mathrm{M}^{3}\right)$ is decreasing in Building designed with shear wall than Buildings Designed with only Moment Resisting Frames for all cases

\section{REFERENCES}

[1] Park, R. \& Paulay, T, Reinforced concrete structures / R. Park, T. Paulay. (2009). 10.1002/9780470172834.ch5.

[2] T Paulay and M.J.N. Priestley Seismic Design of Reinforced Concrete and Masonary Buildings, DOI:10.1002/9780470172841

[3] P C Verghese, "Design of Reinforced Concrete Structure" (2010)

[4] Misam.A and Mangulkar Madhuri.N, Structural Response of Soft Story-High Rise Buildings Under Different Shear Wall Location, International Journal of Civil Engineering and Technology (IJCIET), Volume 3, Issue 2, July- December (2012)

[5] Mark Fintal Hanbook of Concrete Engineering

[6] D. J. Dowrick, "Earth quake resistance design: a manual for Engineers and Architecsts", Wiley 1977.

[7] Mark Fintal "Shear Wall - An answer for Seismic resistance?" Article of Concrete International, July 1991

[8] K Venkatesh and T. Venkatdas, Study on Seismic Effect of High Rise Building Shear Wall/Wall Without Shear Wall 8(1), 2017, pp. 852-862.

[9] Sudhir Jain and Manoj Madhekar Seismic behavior design and Detailing of R.C. shear walls Part I and II, Synopsis, Indian Concrete Journal, July 1993

[10] V Kapur Ashok K Jain "Seismic response of shear wall frames versus braced Concrete Frames" Article of Indian Concrete Journal, April 1983

[11] Dr.J.Premalatha, R. Shanthi Vengadeshwari and Abhijith B, Study On The Behaviour of Multistoreyed Steel Framed Building with Steel Plate Shear Walls Under Seismic Forces, International Journal of Civil Engineering and Technology, 8(9), 2017, pp. 361-370.

[12] Ahmet E. Aktan and Vitelmo V. Bertero "Conceptual Seismic design of frame wall structure" Article of ASCE, Nov- 1984

[13] Israa H. Nayel, Shereen Q. Abdulridha, Zahraa M. Kadhum, The Effect of Shear Wall Locations in RC Multistorey Building with Floating Column Subjected To Seismic Load, International Journal of Civil Engineering and Technology, 9(7), 2018, pp. 642-651

[14] CVR Murthy, IIT Kanpur, "Why are buildings with shear walls preferred in Seismic regions" Earth quakes Tips, Nov-2005 